\title{
Perceptions of Small and Medium Enterprises on IFRS Adaptation Process: a Case Study in Federation of Bosnia and Herzegovina
}

\author{
Uğur Ergun ${ }^{1} \&$ Elif Öztürk ${ }^{2}$ \\ ${ }^{1}$ Faculty of Economics, International Burch University \\ ${ }^{2}$ Faculty of Economics, International Burch University
}

Correspondence: Elif Öztürk, Francuske revolucije bb, Ilidža, 71000 Sarajevo, Bosnia and Herzegovina. Tel: 387-33-944-400. Fax: 387-33-782-131. E-mail: eozturk@ibu.edu.ba

Received: March 9, 2013

Accepted: March 29, 2013

Online Published: April 1, 2013

doi:10.5430/jbar.v2n1p43

URL: http://dx.doi.org/10.5430/jbar.v2n1p43

\begin{abstract}
This study investigates the problems with the implementation process of the International Financial Reporting Standards for Small \&Medium Enterprises in Federation of Bosnia \& Herzegovina. The factor analyses method is used over the two hundred and fifty seven survey responses obtained from companies operating in Sarajevo. Empirical findings indicate that; (a) Small and Medium Enterprises have positive perception on International Financial Reporting Standards, (b) the companies don't have enough information about International Financial Reporting Standards and, (c) conversion process of financial reporting system is complicated.
\end{abstract}

Keywords: Bosnia \& Herzegovina, International financial reporting standards, Implementation process, Factor analyses, Small \& medium enterprises

\section{Introduction}

The International Financial Reporting Standards (IFRS) are a set of financial reporting principles which aim to create a single, world-wide reporting language for the financial sector. Globalization and economic unions encourage companies to use the same financial reporting standards in order to ease bilateral trade relations. The differences among countries' financial reporting methods have a negative impact and make it difficult for investors to evaluate each company's performance. The IFRS provide a more reliable form of financial reporting for companies operating all over the world and makes it possible for companies to lower the costs of preparing different financial statement tables for each different country. Still, each company that operates internationally has to prepare its financial statements in compliance with the countries with which it has business deals.

In Federation of Bosnia and Herzegovina ( $\mathrm{FBiH}$ ), international accounting standards (IAS) started to be used on the $1^{\text {st }}$ of January, 1995. The priority of this implementation included the preparation and introduction of balance sheets for private institutions. Both public and international experts had a role in the process of perfectly introducing IAS to the public. Additionally, higher education institutions added new financial courses related to the accounting reforms to their curriculum. In 1997, the Federal Agency for Accounting and Auditing was established with the main goal of achieving the shared unity for its improvement and function in Bosnian society: A Codex was made of accountancy principles and standards in $\mathrm{FBiH}$, as well as seventeen accounting standards along with classification accounts for firms, which were announced in the first book of the Institute for Accountancy and Revision of FBiH. Since 2005, accounting policy has been determined by a law that includes the implementation of the international accounting system. Afterwards, companies started to convert their system to the international one.

The responsible institutions, such as the Agency for Accounting and Audits, the Federal Law on Accounting and the Federal Association of Professional Accountants, studied all the standards in an effort to harmonize the Bosnian financial reporting system with the international reporting system. Those standards were published in the official papers 50/98 of $\mathrm{FBiH}$. In the first phase of application, the Agency for Accounting and Audits revealed the factors 
that had had negative effects on the implementation of the international standards such as lack of documents, fraud and errors, and weakness of internal control.

A framework is developed to gauge the real situation of the IFRS on SME and adaptation process in FBiH. The data is obtained through face to face surveys and evaluated by using factor analysis in SPSS. The study reveals the real perceptions of SME companies regarding the IFRS in FBiH and investigates the perceptions of companies in order to understand the problems occurred in the adaptation process to the IFRS. The remainder of this paper is organized as follows: Section 1 includes a review of the literature on global IFRS applications. Section 2 describes the data and methodology used in this research. Section 3 presents the empirical results and Section 4 reports the conclusion and implications.

\section{Literature Review}

Prior studies explain the early adoption of the IFRS according to firm-specific benefits (Renders \& Gaeremynck, 2007), in particular, the implementing of the IFRS to increase quality and reliability as well as reduce the cost of adopting them for the firms mentioned by Daske (2006) and Daske and Gebhardt (2006). However, some researchers, such as Schadewitz \& Vieru (2009), believed that changing the legal system to the IFRS increased auditing costs. They stress that audit costs are likely to increase in order to guide employees and clients in implementing the new accounting policies.

Most countries in the European Union have already implemented the International Financial Reporting System (IFRS). By 2005, every listed European Union country was required to produce its group financial statements in full accordance with the International Accounting Standards and International Financial Reporting Standards (Alexander et.al, 2003).

Some researchers believe that it is more beneficial to require companies to implement the system (IFRS) rather than letting the switch be voluntarily. According to these researchers, the change was more efficient for the firms who implemented the IFRS on a compulsorily basis than for those that adapted to the IFRS system voluntarily. However, there are some studies written on the impact of the adoption of the IFRS focusing on the characteristics of the firms that voluntarily adopted the standards, such as Murphy (1999), El-Gazzar et al. (1999) and Ashbaugh (2001).

Coffee (1984), Dye (1990), Lambert et al. (2007) stress that the IFRS applications improve comparisons across firms and reduces estimation risk and conversion to the IFRS provides positive externalities on other firms, and mandating the IFRS would be one way to capture them. On the other hand, some researchers believe that the IFRS system has a negative impact on firms. Botosan (1997), Botosan \& Plumlee (2002), Francis et al. (2004), and Hail \& Leuz (2006) show that more extensive financial disclosures and higher quality reporting are negatively related to firms' cost of equity capital.

Additionally, some studies, such as Judge et al.(2010), seek to understand why some economies have quickly embraced the IFRS while others only partially adopt the IFRS and still others continue to resist. Their findings show that the institutional pressures within an economy are the key drivers in the adoption of the IFRS. Christensen, et al. (2009) explains that the mandatory adoption of the IFS has an impact on debt contracting.

Chen, et al. (2010) studied the effect of the IFRS on accounting quality and the difficulties in controlling the confounding factors on accounting quality and stated that the quality of financial reporting increases with the implementation of the IFRS. Ball et.al (2003) question the quality of the financial statements prepared under the IFRS standards, particularly in the presence of weak enforcement mechanisms and adverse reporting incentives. In addition, some authors such as Chen \& Cheng (2007) believe that using the International Financial Reporting Standards offers no contribution to the companies. They indicate the lack of significant contribution to the harmonization process to reform corporate governance.

Finally, it can be stated that the studies focus on the impact of the IFRS and that the IFRS give companies the opportunity to compare their financial statements with others.

\section{Methodology}

The data is obtained through face to face surveys with two hundred and fifty seven companies from different industries operating in Sarajevo. Sixty-four of the responses were omitted in order to increase the reliability of the sample. Survey responses were analyzed using the factor analysis method in SPSS. The survey is also designed based on the objective of the paper and fourteen questions were included. Each question was followed by a five-point Likert scales ranging from strongly disagree to strongly agree. 
The origin of factor analysis is generally ascribed to Charles Spearman (Harman, 1976). The essential purpose of factor analysis has been well expressed by Kelley (1940, p.120): The statistical package for social sciences (SPSS) is used to analyze the results obtained from the questionnaire (Leng et al., 2008). It is also used to analyze the results of this survey.

Factor analysis is a statistical method used to describe variability among observed variables in terms of a potentially lower number of unobserved variables called factors. Factor analysis searches for such joint variations in response to unobserved latent variables. The observed variables are modeled as linear combinations of the potential factors, plus error terms. Factor analysis originated in psychometrics and is used in the other applied sciences to deal with large quantities of data.

\section{Empirical Results}

In the first step, survey results are analyzed and in the second step responses were scrutinized for patterns through factor analytic methods using the SPSS software program in all procedures reported in the study. The Principal Axis Factor was used as the default setting and to determine the factor loadings greater than 0.30 . After the verification of the Kaiser-Meyer Olkin measure of sampling adequacy (must be over 0.60) and determining the number of factors, it is proceeded in this study to rotate the matrix of loadings to obtain orthogonal factors using varimax rotation (Kaiser, 1958). The component loading results are reported in Table below. In the third step, Kaiser Strategy (1960) is one method to use and dropped all components with eigenvalues smaller than 1.0 then repeated the procedures setting the loading size cut-off value at 0.60 to obtain a rotated second matrix of loading. In the last step, factors were identified and compared with the results obtained from the two approaches.

A principal component analysis with a Varimax orthogonal rotation of the 5 scale questions from the survey questionnaire is conducted on the survey data gathered from 257 participants and define the three topic factors loadings as follows;

The table 1 indicates three factors which has items loaded on each. Seven items are loaded in Factor 1 which are; whether the companies are agree or not to make the standards mandatorily, whether to be adapted to the IFRS is important for companies or not, do the companies agree or not IFRS makes investments efficient or not, whether the companies believe or not at least a quarter of all Bosnian firms will be using IFRS the next five years, do companies agree or not using of IFRS-1 and IAS-1 by other European countries will provide major contribution of harmonization process of IFRS in and do the companies agree or not using IFRS will accelerate economic growth of Bosnia.

Three items are loaded in Factor 2 which are; lack of knowledge about IFRS, lack of educated staff and language problem. This factor shows that there is lack of knowledge about IFRS. This factor is labeled as "lack of knowledge".

The items loaded in Factor 3 are; differences about the level of education of accountant, complexity of conversion, dissonance of internal reporting and external reporting, lack of consistent IFRS application globally. This Factor is labeled as "complexity of adaptation".

\section{Conclusion}

This paper investigates the perception of SMEs regarding the International Financial Reporting Standards implementation in the Federation of Bosnia and Herzegovina. The data is obtained through a face to face survey study of two hundred and fifty-seven companies operating in Sarajevo. Factor analyses were performed using the SPPS package.

The analysis results indicate that; (a) the SME companies have positive perception about using International Financial Reporting Standards (IFRS), (b) the companies don't have enough information about International Financial Reporting Standards, (c) conversion process related to financial reporting system is complicated. This complexity is perceived as a difficulty in front of companies to implement this financial reporting system. This study has important implications regarding the application of the IFRS on SME in FBiH and provides beneficial information for the policy makers who are responsible for the implementation process. Also, this study sheds light on the real situation of the International Financial Reporting Standards in Bosnia \& Herzegovina. 
Table 1. Rotated Component Matrix ${ }^{\mathrm{a}}$

\begin{tabular}{|c|c|c|c|}
\hline & \multicolumn{3}{|c|}{ Component } \\
\hline & 1 & 2 & 3 \\
\hline 1 Do you agree with that the use of standards should be optional? & .361 & & \\
\hline 2 Do you agree with that use of standards should be mandatory? & .680 & & \\
\hline $\begin{array}{l}3 \text { Do you agree with that is important for you to be adapted to the IFRS as } \\
\text { a company? } \\
4 \text { Do you agree with that the use of IFRS will make investments efficient? }\end{array}$ & 639 & & \\
\hline $\begin{array}{l}5 \text { Do you believe that at least a quarter of all Bosnian firms will be using } \\
\text { IFRS the next five years? }\end{array}$ & .680 & & \\
\hline $\begin{array}{l}6 \text { Do you agree with that using of IFRS- } 1 \text { and IAS- } 1 \text { by other European } \\
\text { countries will provide major contribution of harmonization process of } \\
\text { IFRS in Bosnia? }\end{array}$ & .766 & & \\
\hline $\begin{array}{l}7 \text { Do you agree with that using IFRS will accelerate economic growth of } \\
\text { Bosnia? }\end{array}$ & .744 & & \\
\hline $\begin{array}{l}8 \text { Do you agree with that the all Bosnian firms be forced to use IFRS, } \\
\text { instead of their legal accounting system in financial statements filed with } \\
\text { SEC? }\end{array}$ & .686 & & \\
\hline $\begin{array}{l}9 \text { Overall, how would you rate privately held Bosnian should be permitted } \\
\text { to use 'IFRS for private entities' when preparing their financial statements? }\end{array}$ & .579 & & \\
\hline \multirow[t]{2}{*}{10 Cost } & .306 & & .328 \\
\hline & & & \\
\hline 11 Differences about the level of education of accountant & & & .621 \\
\hline 12 Complexity of conversion & & & .687 \\
\hline 13 Dissonance of internal reporting and external reporting & & & .722 \\
\hline 14 Lack of consistent IFRS application globally & & & .689 \\
\hline 15 Existing regulations that are not related with tax system & & & .537 \\
\hline 16 The role of tax rates & & & \\
\hline 17 Lack of knowledge about IFRS & & & \\
\hline 18 Lack of educated staff & & & \\
\hline $\begin{array}{l}19 \text { Changing of the accounting law system by government during the } \\
\text { adaptation process }\end{array}$ & & & \\
\hline 20 Language problem & & & \\
\hline 21 Lack of enough expert in the country & & & \\
\hline 22 Standards that are approved by government are not translated on time & & & \\
\hline $\begin{array}{l}23 \text { Lack of awareness about the importance of IFRS for foreign } \\
\text { investments }\end{array}$ & & & \\
\hline
\end{tabular}

Extraction Method: Principal Component Analysis. Rotation Method: Varimax with Kaiser Normalization.

\section{References}

Alexander, D., Britton, A. \& Jorissen, A. (2003). International Financial Reporting and Analysis, (Thomson Learning, LondonBall).

Ashbaugh, H. (2001). Non-US Firms' Accounting Standards Choice, Journal of Accounting and Public Policy, 20 (2), pp.129-153. http://dx.doi.org/10.1016/S0278-4254(01)00025-4 
Ball, R., A. Robin, \& J. S. Wu. (2003). Incentives versus standards: properties of accounting income in four East Asian countries. Journal of Accounting and Economics. 36: 235-270. http://dx.doi.org/10.1016/j.jacceco.2003.10.003

Botosan, C. \& Plumlee, M. (2002) A re-examination of disclosure level and the expected cost of equity capital. Journal of Accounting Research, 40, pp.21-40. http://dx.doi.org/10.1111/1475-679X.00037

Botosan, C. (1997). Disclosure level and the cost of equity capital. The Accounting Review, 72, pp. 323-349. http://www.jstor.org/stable/248475

Chen, J. \& Cheng, P. (2007). Corporate Governance and Harmonization of Chinese Accounting Practices with IFRS Practices, Corporate Governance: an International Review, 15, pp. 284-293. http://dx.doi.org/10.1111/j.1467-8683.2007.00560.x

Chen, F., Hope, O.-K., Li, Q. \& Wang, X. (2010). Financial Reporting Quality and Investment Efficiency of Private Firms in Emerging Markets (July, 2010). [Online] Available: http://ssrn.com/abstract=1635425

Christensen, H., Lee, E. \& Walker, M. (2008). Incentives or standards: what determines accounting quality changes around IFRS adoption? Working paper, Manchester Accounting and Finance Group and Manchester Business School. http://dx.doi.org/10.1016/j.jacceco.2006.10.002

Christensen, H. B., Lee, E. \& Walker, M. (2009). Do IFRS Reconciliations Convey Information? The Effect of Debt Contracting. Journal of Accounting Research, 47: 1167-1199. http://dx.doi.org/10.1111/j.1475-679X.2009.00345.x

Coffee, J. (1984). Market Failure and the Economic Case for a Mandatory Disclosure System, Virginia Law Review, 70, pp. 717-753. http://dx.doi.org/10.1016/j.jacceco.2006.10.002

Dye, R. (1990). Mandatory versus voluntary disclosures: The cases of financial and real externalities. The Accounting Review, 65, pp. 1-24.

Daske, H. (2006). Economic benefits of adopting IFRS or US-GAAP-have the expected cost of equity capital really decreased? Journal of Business Finance and Accounting, 33 (3-4), pp.329-373. http://dx.doi.org/10.1111/j.1468-5957.2006.00611.x

Daske H.,Gebhardt G. (2006). International Financial Reporting Standards and Experts Perceptions of Disclosure Quality, Vol.42, No. 3-4, pp. 461-498, Abacus.

Daske, H., Hail, L., Leuz, C. \& Verdi, R. (2007). Adopting a label: heterogeneity in the economic consequences of IFRS adoptions. Working paper, Goethe University of Frankfurt, University of Pennsylvania, University of Chicago, and MIT.

Daske, H., Hail, L., Leuz, C. \& Verdi, R. (2008). Mandatory IFRS reporting around the world: early evidence on the economic consequences, Journal of Accounting Research, 46 (5), pp. 1085-1142. http://dx.doi.org/10.1111/j.1475-679X.2006.00209.x

El-Gazzar S., Finn P. \& Jacob R. (1999). An Empirical Investigation of Multinational Firms' Compliance with International Accounting Standards, The International Journal of Accounting, 34 (2), pp. 239-248. http://dx.doi.org/10.1016/S0020-7063(99)00005-9

Francis, J., LaFond, R., Olsson, P. \& Schipper, K. (2004). Costs of equity and earnings attributes. The Accounting Review, 79, pp. 967-1010. http://dx.doi.org/10.2308/accr.2004.79.4.967

Hail, L. \& Leuz, C. (2006). International Differences in the Cost of Equity Capital: Do Legal Institutions and Securities Regulation Matter? Journal of Accounting Research, 44 (June), pp. 485-531. http://dx.doi.org/10.1111/j.1475-679X.2006.00209.x

Harman H. H. (1976). Modern Factor Analysis, University Of Chicago Press. http://dx.doi.org/10.1177/014662168801200305

Judge W., Li S. \& Pinsker R. (2010). National Adoption of International Accounting Standards: An Institutional Perspective, Corporate Governance: An International Review, 18 (3), pp. 161-174. http://dx.doi.org/10.1111/j.1467-8683.2010.00798.x

Kelley, T. L. (1940). Comment on Wilson and Worcester's Note on Factor Analysis. Psychometrika, 5, p.120. http://dx.doi.org/10.1007/BF02287869 
Kaiser H F. (1958). The Varimax Criterion for Analytic Rotation in Factor Analysis, Psychometrika, 23, pp.187-200. http://dx.doi.org/10.1007/BF02289233

Kaiser, H. F. (1960). The Application of Electronic Computers to Factor Analysis. Educational and Psychological Measurement, 20, pp. 141-151. http://dx.doi.org/10.1111/j.1475-679X.2007.00238.x

Lambert, R., Leuz, C. and Verrecchia, R.E. (2007). Accounting Information, Disclosure, and the Cost of Capital, Journal of Accounting Research, 45 (May), pp.385-420. http://dx.doi.org/10.1111/j.1475-679X.2007.00238.x

Leng L.T., Lazar J. \& Othman R. (2008). Adoption of International Financial Reporting Standards in Malaysia, $M O D A V$.

Murphy, A. (1999). Firm Characteristics of Swiss Companies that Utilize International Accounting Standards, The International Journal of Accounting, 34 (1), pp.21-131. http://dx.doi.org/10.1108/02686901211236409

Renders A. \& Gaeremynck A. (2007). The Impact of Legal and Voluntary Investor Protection on the Early Adoption of IFRS, De Economist, 155 (24), pp.49-72. http://dx.doi.org/10.1007/s10645-006-9041-y

Schadewitz, H \& Vieru, M. (2009). Impact of IFRS transition complexity on audit and non-audit fee: Evidence from small and medium-sized listed companies in Finland. Working paper, [Online] Available: http://ssrn.com/abstract $=967314$ 